\title{
RT-PCR based detection and adaptation of foot and mouth disease virus serotype " $A$ " in BHK-21 cell line
}

\author{
MR Quddus ${ }^{1}$, ML Hossen ${ }^{2}$, MMR Chowdhury², T Chakrobarty ${ }^{3}$, S Mahmud $^{4}$, KHMNH \\ Nazir $^{2}$, KM Nasiruddin ${ }^{1}$, MB Rahman ${ }^{2 *}$ \\ ${ }^{1}$ Department of Biotechnology, ${ }^{2}$ Department of Microbiology and Hygiene, ${ }^{3}$ Department of Genetics and Plant \\ Breeding, ${ }^{4}$ Department of Biochemistry and Molecular Biology, Bangladesh Agricultural University, \\ Mymensingh 2202, Bangladesh
}

\begin{abstract}
The economic consequences of an outbreak of Foot and Mouth Disease (FMD) in Bangladesh is devastating. A sensitive, reliable and rapid diagnosis is crucial for the effective control of FMD. The present research was conducted for quick molecular detection and adaptation of FMD virus (FMDV) in BHK-21 (Baby Hamster Kidney) cell line. A two-step RT-PCR method was applied for the detection of the FMDV. Without prior adaption into BHK-21 cell culture, it is difficult to detect FMDV directly from the field samples by RT-PCR method. Samples were collected from the tongue epithelium $(\mathrm{N}=19)$ and inter digital tissues $(\mathrm{N}=4)$ of the suspected animals in Sujanagar, Bera, Santhia of Pabna district and Kotowali, Trishal of Mymensingh districts of Bangladesh during the year 2014. BHK-21 cell subculture was done from a previously cultured bottle containing BHK-21 cells. Prepared inocula were inoculated into BHK-21 cell culture and incubated at $37^{\circ} \mathrm{C}$ for $24 \mathrm{~h}$. After $36 \mathrm{~h}$, cytopathic effects (CPE) were observed in BHK-21 cell line characterized by rounding and flattening of the cells, multinucleated giant cells formation, breaking down of the intracellular bridges and finally cell death indicated the presence of FMDV. Clear infectious BHK-21 cell culture fluid was collected and preserved at $-20^{\circ} \mathrm{C}$ temperature for virus detection by RT-PCR with serotype specific primers. Viral RNA was extracted from the clear infectious cell culture fluid for cDNA synthesis and used for PCR. Out of 23 samples tested, 3(13.04\%) were positive for FMDV serotype A. The findings of this study can be helpful for the selection of vaccine having specific FMDV type, and it may help in controlling FMD in Bangladesh.
\end{abstract}

Key words: BHK-21 cell line, cytopathic effect, FMDV, RT-PCR

Progressive Agriculturists. All rights reserve

*Corresponding Author: bahanurr@gmail.com

\section{Introduction}

Foot and Mouth disease virus (FMDV) is a nonenveloped, single stranded, positive sense RNA genome, approximately 8,500 bases surrounded by four structural proteins (VP 1-4) to form an icosahedral capsid (Rueckert et al., 1996). Seven serotypes of FMD virus such as O, A, C, SAT-1, SAT-2, SAT-3 and Asia-1 and at least 65 subtypes have been identified (Rahman and Mozumder et al., 1991; Le et al., 2012; Olabode et al., 2014). Infection with one serotype does not confer immunity against another (OIE, 2009).
The foot and mouth disease virus (FMDV) is the pathogen that causes Foot and Mouth disease (Carrillo et al., 2005). FMD is one of the major threats for the development of livestock population in Bangladesh (Rahman et al., 2011). Outbreak of FMD causes severe economic losses to the livestock industries in terms of loss of draft power, meat and milk production, infant and adult animal mortality (Chowdhury et al., 1993; Zinnah et al., 2010; Belsham and Botner, 2015). Annual loss due to FMD in Bangladesh has been estimated at about US\$62 
million (FAO/OIE, 2012). The infection is highly contagious, and can infect domestic and wild animals with cloven hooves. These along with continuous changing of the virus property make it difficult for the professionals in this field to combat the disease (Zabal et al., 2013).

FMDV serotype O, A and Asia-1 are the currently circulating FMDV in Bangladesh as revealed by RTPCR (Chowdhury et al., 2016). Mixed infection having Type A and Asia-1 FMDV was also detected (Hossen et al., 2014). Epidemiological investigation of this virus in cattle population indicated that four different types (A, O, C and Asia-1) of FMDV were prevalent in Bangladesh during 1960 to 1990 (Chowdhury et al., 1996). FMDV Serotype "A" and "O" were consistently present in Bangladesh during 1996 to 2000 (Islam et al., 2000). The recent studies indicated that three different types (A, Asia-1 and O) were prevalent in Bangladesh during 2007 to 2008 (Sil and Taimur, 2000; Zinnah et al., 2010; Nandi et al., 2013). Serotype "O" was found to be responsible for $80 \%$ of the confirmed outbreaks, whereas "Asia 1 " and "A" caused $12 \%$ and $8 \%$ outbreaks, respectively (Sarker et al., 2011; Hossen et al., 2014).

Although every year vaccination is carried out throughout the country against FMD, still the disease outbreak occurs in many parts of Bangladesh (Sarker et al., 2011). Recent report from FAO has recommended that surveillance and reporting of FMD needs to be improved throughout the country. Furthermore, all suspected clinical cases of FMD should be confirmed by laboratory examination (Mondal and Yamage, 2014).

Therefore, the present study was undertaken to identify the FMDV serotype "A" from Pabna and Mymensingh district of Bangladesh. It will help for the selection of vaccination, and strategies for the control of FMD in Bangladesh to improve the economy of farmers.

\section{Materials and Methods}

Location and period of the study. The study was carried out with the help of Tissue culture laboratory, Virology Laboratory, Food Hygiene laboratory, and Molecular laboratory in the Department of Microbiology and Hygiene, Bangladesh Agricultural
University, Mymensingh. Period of the study was July, 2014 to June, 2015.

Sample collection. Samples were collected from the tongue epithelium $(\mathrm{N}=19)$ and inter digital tissue $(\mathrm{N}=4)$ of the suspected animals from Sujanagar, Bera, Santhia of Pabna district and Kotowali, Trishal of Mymensingh district of Bangladesh during the year 2014. Among 23 samples, 16 samples were collected from Pabna district and 7 samples were collected from Mymensingh district.

Subculture of BHK-21 cell. All the media and reagents were brought to room temperature before use. The growth media from the flask containing BHK-21 cell culture was removed. Then the monolayer cells were washed with sterile IX PBS for 2 times. One milliliter $(1 \mathrm{ml})$ of trypsin was added into the flask and mixed with the cell to detach the cells from the wall of the tissue culture flask. The flask was left in the incubator for $5 \mathrm{~min}$. The tissue culture flask was shaken up and down smoothly to spread trypsin until detachment of the BHK-21 cell line. About $500 \mu \mathrm{l}$ growth media was added to the flask. Cell aggregation was broken by pipetting and depipetting. $10 \mathrm{ml}$ of media containing cell was poured into $25 \mathrm{~cm}^{2}$ flask. The flask was allowed to incubate at $37^{\circ} \mathrm{C}$ for $24 \mathrm{~h}$.

Adaptation of FMDV in BHK-21 cell culture. The cells those formed confluent mono-layers in the culture flask within $24 \mathrm{~h}$ of incubation were selected for infection with viruses. The growth media from the flask containing BHK-21 cell was removed and then the monolayer calls were washed with $1 \mathrm{X}$ sterile PBS for 2 times. One milliliter (1ml) of virus inoculum was added to the flask containing confluent monolayer of BHK-21 cells. The inoculum was spread over the monolayer cell by tilting for about 45-60 min for the establishment of better interaction. Then $10 \mathrm{ml}$ of the maintenance media $(1 \times \mathrm{MEM}$ supplemented with $2 \%$ heat inactivated fetal calf serum) was added in a $25 \mathrm{~cm}^{2}$ flask and the vessel was returned to the incubator. Virus added flask was allowed to incubate at $37^{\circ} \mathrm{C}$. The cells were examined twice daily under inverted microscope until show characteristic cytopathic effect (CPE) by Foot and Mouth disease virus (FMDV). The cells were examined under inverted microscope. FMD virus produced cytopathic effects (CPE) in the BHK- 
21 cell at different intervals of post infection (24 to $96 \mathrm{~h}$ ) which was characterized by the rounding and flattening of the cells, breaking down of the intracellular bridges and finally cell death which are characteristic findings of FMDV infected cells. Initially the growth of virus in BHK-21 cell line was lower, which increased after, subsequent 3 time's passage of infection into BHK-21 cell line.

Viral RNA extraction and RT-PCR. The infectious fluid containing FMDV was harvested after $48 \mathrm{~h}$ to $72 \mathrm{~h}$ of post infection. Viral RNA extraction from the infectious cell culture fluid was carried out according to the instructions of the manufacturer using SV Total RNA Isolation System (Promega, USA). Manufacturer protocol was followed for the conduction of RT-PCR using Access RT-PCR system (Promega, USA) and specific primers (Table 1). The thermal profile used for cDNA synthesis was $45^{\circ} \mathrm{C}$ for $45 \mathrm{~min}$ and $94^{\circ} \mathrm{C}$ for $2 \mathrm{~min}$ for one cycle. Thermal profile for PCR amplification was: initial denaturation at $94^{\circ} \mathrm{C}$ for $5 \mathrm{~min}$, denaturation at $94^{\circ} \mathrm{C}$ for $30 \mathrm{sec}$, annealing at $60^{\circ} \mathrm{C}$ for $1 \mathrm{~min}$, extension at $68^{\circ} \mathrm{C}$ for $2 \mathrm{~min}$, for 40 cycles, and a final extension at $68^{\circ} \mathrm{C}$ for $7 \mathrm{~min}$. PCR amplified products were separated electrophoretically on $2 \%$ agarose gel and stained with ethidium bromide after electrophoresis.

Documentation of the PCR product. After the PCR products electrophoresis at $100 \mathrm{~V}$ for $35 \mathrm{~min}$ in TAE buffer on $2 \%$ agarose gel, the gel was subjected to ethidium bromide $(0.6 \mathrm{mg} / \mathrm{ml})$ for $10 \mathrm{~min}$. The gel gently washed in running tap water and placed on the UV-transilluminator (Bio Rad, USA) in the dark chamber for the image documentation. The positive samples were recorded based on the appearance of expected size of band in the gel.

Table 1. List of the primers used for the detection of FMD virus serotype "A"

\begin{tabular}{|c|c|c|c|c|}
\hline $\begin{array}{c}\text { FMDV } \\
\text { Serotype }\end{array}$ & $\begin{array}{c}\text { Primer } \\
\text { Designation }\end{array}$ & Sequence(5'-3') & $\begin{array}{c}\text { PCR products } \\
\text { size (bp) }\end{array}$ & Reference \\
\hline A & FMDA F & TACCAAATTACACACGGGAA & 866 & Reid et al., (2000) \\
\hline
\end{tabular}

\section{Results and Discussion}

All the inocula were inoculated into BHK-21 cell line for the isolation of viruses. Out of 23 samples tested, 3 (13.04\%) were found positive for FMDV serotype A (Table 2 and 3). The cytopathic effect produced by the inocula of FMDV in BHK-21 cells were manifested by the rounding and flattening of the cells, breaking down of the intracellular bridges and finally cell death which are characteristic findings of FMDV infected cells (Figure 1). The findings of cell culture following infection with FMDV were similar with the findings of Hossen et al., (2014), Islam et al. (2000), Shahiduzzaman (2012) and Alam et al. (2015).

Rapid detection and identification of FMDV and its serotypes is important and essential both in animal health and control of FMD. Molecular biology is providing extremely sensitive and specific tools for identifying and characterizing FMDV strains in clinical samples (King, 2001).
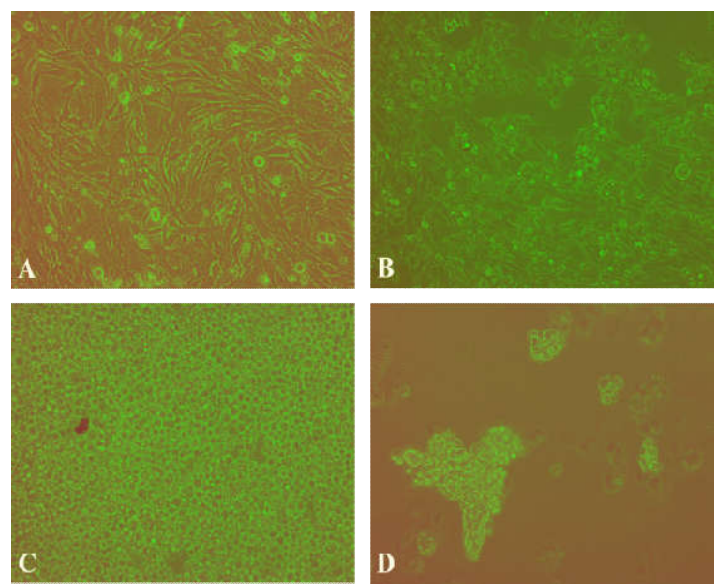

Figure 1. A: Uninfected BHK-21 Cell (Elongated shape, Close packing of the cells, Little intercellular space), and B, C and D: FMDV infected BHK-21 cell showing cytopathic effect (CPE) (B: $1^{\text {st }}$ passage: Initiation of infection and cell rounding started after $24 \mathrm{~h}$ of infection, $\mathrm{C}: 2^{\text {nd }}$ passage: Almost $95 \%$ cell infected after $36 \mathrm{~h}$ of infection, D: 3rd passage: Almost $100 \%$ cell infected after $48 \mathrm{~h}$ of infection observed under 200X (Carlt Zeiss, Germany). 
The molecular detection technique is rapid, accurate, highly sensitive and only small quantities of material are needed to do the test. Detection of FMDV serotypes by means of RT-PCR has been described before (Alam et al., 2015; Hossen et al., 2014; Marupanthorn et al., 2013; Le et al., 2012; Loth et al., 2011; Saeed et al., 2011). We have performed the PCR after synthesis of cDNA from the extracted RNA of the FMD virus and found positive bands at $866 \mathrm{bp}$ after electrophoresis in $2 \%$ agarose gel which was specific for FMDV serotype "A" (Figure 2).

Table 2. Detected FMDV serotypes by two step RT-PCR

\begin{tabular}{|c|c|c|c|}
\hline Sample size & Sample adapted in cell culture & $\begin{array}{c}\text { Positive serotype of } \\
\text { FMDV by RT-PCR }\end{array}$ & $\begin{array}{c}\text { No. of positive } \\
\text { sample }\end{array}$ \\
\hline $\begin{array}{c}\text { Tongue epithelium } \\
(\mathbf{N}=\mathbf{1 9})\end{array}$ & $\begin{array}{c}\text { Tongue epithelium } \\
19(100 \%)\end{array}$ & FMDV serotype “A” & $3(15.79 \%)$ \\
\hline $\begin{array}{c}\text { Foot samples } \\
(\mathbf{N}=\mathbf{4})\end{array}$ & $\begin{array}{c}\text { Foot samples } \\
2(50 \%)\end{array}$ & FMDV serotype “A” & 0 \\
\hline \multicolumn{2}{|r|}{ Total } & $3(13.04 \%)$ \\
\hline
\end{tabular}

Table 3. Name of the locality found positive for FMDV serotype "A"

\begin{tabular}{|c|c|c|c|}
\hline Country name & Locality & $\begin{array}{c}\text { Total no. of } \\
\text { sample tested }\end{array}$ & $\begin{array}{c}\text { Samples found positive } \\
\text { For FMDV serotype "A" }\end{array}$ \\
\hline \multirow{2}{*}{ Bangladesh } & Pabna district (Sujanagar, Bera, Santhia) & 16 & $3(18.75 \%)$ \\
& Mymensingh district (Kotowali, Trishal) & 7 & $0(0.00 \%)$ \\
\hline \multicolumn{2}{|c|}{ Total } & 23 & $3(13.04 \%)$ \\
\hline
\end{tabular}

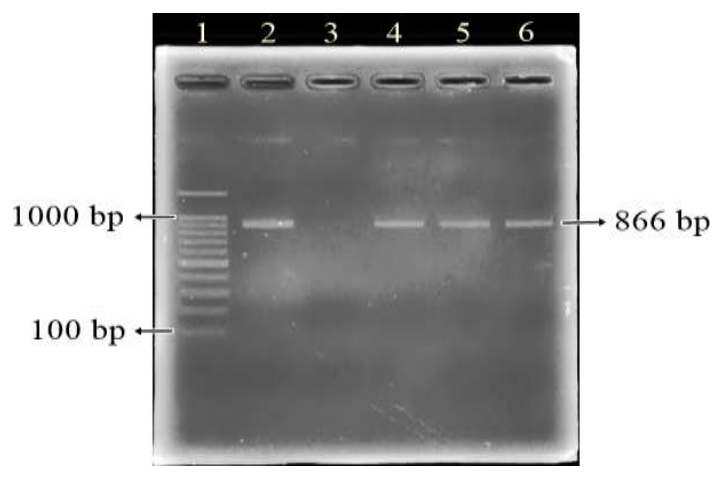

Figure 2. Image showing that Lane $1=100 \mathrm{bp}$ DNA marker, Lane 2=positive control, Lane $3=$ negative control, lane 4,5 and $6=866 \mathrm{bp}$ DNA band for FMDV serotype A following $2 \%$ agarose gel electrophoresis

\section{Conclusion}

Present study proved that FMDV serotype "A" is present in the Pabna district of Bangladesh. RT-PCR technique followed by BHK-21 cell adaptation of virus is very sensitive method of FMDV isolation and identification and can be used for the detection of FMD virus serotype. In future, the research findings may be used for the preparation of vaccine against FMDV.

\section{Acknowledgement}

Author is grateful to the Ministry of Science and technology, Government of the People's Republic of Bangladesh for the assignation of National Science and Technology Scholarship which has partly supported the work.

\section{References}

Alam MA, Rahman M, Hossen ML, Ahmed S, Parvej MS, Khan MFR, Rahman MB (2015). Reverse transcription polymerase chain reaction (RT-PCR) based detection and serotyping of FMD Virus from field samples of Gazipur, Bangladesh, and adaptation of the virus in BHK-21 cell. J. Adv. Vet. Anim. Res. 2(3):291-295.

Belsham GJ, Botner A (2015). Use of recombinant capsid proteins in the development of a vaccine against the foot-and-mouth disease virus. Virus Adaptation and Treatment, 7: 11-23. 
Carrillo C, Tulman ER, Delhon G, Lu Z, Carreno A, Vagnozzi A, Kutish GF, Rock DL (2005). Comparative genomics of foot-and-mouth disease virus. J. Virol. 79:6487-6504.

Chowdhury MMR, Hossen ML, Amin KB, Nazir KHMNH, Ahmed S, Rahman M, Khan MFR, Rahman MT, Rahman MB (2016). Assessment of immune response in cattle against experimentally prepared trivalent $(\mathrm{O}, \mathrm{A}$, and Asia-1) FMD vaccine in Bangladesh. J. Adv. Vet. Anim. Res. 2(4): 475-480.

Chowdhury S, Rahman MZH, Rahman MF, Rahman MB Rahman MM (1996). Strains of foot-andmouth disease virus in different districts of Bangladesh. Asian Australas. J. Anim. Sci. 9(3):315-317.

Chowdhury SMZH, Rahman MF, Rahman MB, Rahman MM (1993). Foot and Mouth Disease and its effect on morbidity, mortality, milk yield and draft power in Bangladesh. Asian Australas. J. Anim. Sci. 6:423-426.

FAO/OIE (2012): FMD virus pools and the regional programmes Virus Pool 2- South Asia. FAO/OIE Global Conference on foot and mouth disease control. Bangkok, Thailand, 2729. June (2012).

Hossen ML, Ahmed S, Khan MFR, Rahman MT, Saha S, Nazir KHMNH, Rahman M, Islam MA, Rahman MB (2014). Typing of Foot and Mouth Disease Virus Circulating in Bangladesh by Reverse Transcription Polymerase Chain Reaction. J. Vet. Adv. 4(12):778-785.

Islam MA, Rahman MM, Adam KH, Marquardt O (2000). Epidemiological implications of the molecular characterization of foot-and mouth disease virus isolated between 1996 and 2000 in Bangladesh. Virus Genes, 23:203-213.

King D (2001). Controlling the foot-and-mouth epidemic briefing from the Government's Chief Scientific Adviser. MAFF website: http://www.maff.gov.uk/animalh/diseases/fmd/1 atest/king.ht.

Le VP, Lee KN, Nguyen T, Kim SM, Cho IS, Khang DD, Hien NB, Van Quyen D, Park JH (2012). A rapid molecular strategy for early detection and characterization of Vietnamese foot-andmouth disease virus serotypes $\mathrm{O}, \mathrm{A}$ and Asia 1. J. Virol. Methods. 180(1-2): 1- 6.
Loth L, Osmani MG, Kalam MA, Chakraborty R K, Wadsworth J, Knowles NJ, Hammond JM, Benigno C (2011). Molecular characterization of foot-and-mouth disease virus: implications for disease control in Bangladesh. Transbound. Emerg. Dis. 58(3):240-246.

Marupanthorn K, Nittayapongchai N, Krachangwong B, Dungdee N (2013): Development of a Multiplex PCR Assay for the Typing of Foot and Mouth Disease in Pigs and Cattle. World Academy of Science, Engineering and Technology, p76.

Mondal SP, Yamage M (2014). A retrospective study on the epidemiology of Anthrax. Foot and Mouth Disease, Haemorrhagic Septicaemia, Peste des Petits Ruminants and Rabies in Bangladesh, (2010-2012). PLoS One. 9(8): DOI: $10.1371 /$ J.pone.0104435.

Nandi SP, Rahman MZ, Momtaz S, Sultana M, Hossain MA (2013). Emergence and distribution of Foot-and-Mouth Disease virus serotype $\mathrm{A}$ and $\mathrm{O}$ in Bangladesh. Transbound. Emerg. Dis. 62(3): 328-331.

OIE (2009). Principles of Veterinary Vaccine Production. In: Manual of Diagnostic Tests and Vaccine for Terrestrial Animals. Version adopted May 2006.Chapter 1.1.7.

Olabode HO, Kazeem HM, Raji MA, Ibrahim ND, Nafarnda WD (2014). Geo-spatial distribution of serologically detected bovine Foot and Mouth Disease (FMD) serotype outbreaks in Ilesha Baruba, Kwara State-Nigeria. J. Adv. Vet. Anim. Res. 1(3): 94-99.

Rahman MM (2011). Progressive control of Foot and Mouth Disease in Bangladesh. BDvet iNewsl. Vol 2. Issue 1. http://bdvets.org/ Vol2_Issue1_FMD.pdf (Accessed on December 1, 2015).

Rahman MM, Mozumder NK (1991). A preliminary study on the epidemiology of FMD virus in Bangladesh. Banglaqdesh J. Microbiol. 8:9396.

Reid SM, Ferris NP, Hutchings GH, Samuel AR Knowles NJ (2000). Primary diagnosis of footand-mouth disease by reverse transcription polymerase chain reaction. J. Virol. Methods. 89:167-176. 
Rueckert RR (1996). Picornaviridae: the virus and their replication. In BN Fields, Knipe DM \& Howley PH (Edn.), Fields Virology, 3ra edn., Lippincott-Raven Publishers, Philadelphia, Pa; pp. 609-654.

Saeed A, Khan QM, Waheed U, Arshad M, Asif M, Farooq M (2011). RT-PCR evaluation for identification and sequence analysis of footand-mouth disease serotype $\mathrm{O}$ from 2006 to 2007 in Punjab, Pakistan. Comp. Immunol. Microbiol. Infect. Dis. 34:95-101.

Sarker S, Talukder S, Haque MH, Islam MH, Gupta SD (2011). Epidemiologicalstudy on foot-andmouth disease in cattle: Prevalence and risk factors assessment in Rajshahi, Bangladesh. Wayamba J. Anim. Sci. March Issue, p. 71-73.

Shahiduzzaman ANM (2012). Serotyping of foot and mouth disease virus from field samples and adaptation in BHK-21 cell line for vaccine seed developmen. MS Thesis, Department of Microbiology and Hygiene, Bangladesh Agricultural University, Bangladesh.
Sil BK, Taimur MJFA (2000). ELISA based techniques for the identification of foot-andmouth disease virus and vaccine evaluation in Bangladesh, 31:49-56. http://www.iaea.org/ inis/collection/NCLCollectionStore/Public/31/0 31/31031686.pdf (Accessed on February 01, 2015).

Zabal O, Fondevila N (2013). Selection of highly susceptible cell lines to Foot and Mouth Disease virus infection. Open J. Vet. Med., 3:263-266.

Zinnah MA, Islam MT, Rahman MM, Hossain MT, Zinnah MA, Bari MR, Haque MH, Khan MSR Islam MA (2010). Standardization of multiplex reverse transcription-polymerase chain reaction and typing of foot-and-mouth disease virus prevalent in Bangladesh. Bangladesh J. Vet. Med. 8:149-155. 